\title{
Effect of age on methane emissions of red deer stags from weaning until one year of age grazing pasture
}

\author{
N.M. Swainson ${ }^{1,2}$, S.O. Hoskin ${ }^{1}$, H. Clark ${ }^{2}$ and N. Lopez-Villalobos ${ }^{1}$ \\ ${ }^{1}$ Institute of Veterinary, Animal and Biomedical Sciences, Massey University \\ PB 11-222, Palmerston North, New Zealand \\ ${ }^{2}$ Rumen, Nutrition and Welfare Section, Food \& Health, AgResearch Limited, \\ Grasslands Research Centre \\ Private Bag 11008, Tennent Drive, Palmerston North, New Zealand
}

\begin{abstract}
The aim of this study was to determine if methane emissions from young farmed deer increase with age. Methane emissions of 20 red deer stags grazing permanent perennial rye grass-based pasture were measured four times post-weaning, at 4.5, 6.5, 9 and 11.5 months of age, using the sulphur hexafluoride technique. Methane production and methane yield increased with age $(\mathrm{P}<0.05)$ and appeared lower $(26 \%)$ than previous measurements from adult deer on similar pasture. These results imply that total methane emissions from young deer recorded in the New Zealand Greenhouse Gas Inventory are likely to be overestimated if values are based on adult methane emissions only.
\end{abstract}

KEY WORDS: methane, pasture, dry matter intake, age, red deer

\section{INTRODUCTION}

Methane emissions from ruminant livestock in New Zealand (NZ) represent 31.3\% of NZ's total greenhouse gas emissions (Anon, 2005); therefore accurate inventories of methane production for all farmed livestock classes are required. Ruminant methane inventories are based on the yield (methane grams per unit of dry matter intake (DMI)), from research conducted in $\mathrm{NZ}$ using the sulphur hexafluoride technique $\left(\mathrm{SF}_{6}\right)$. Methane yield (in the NZ Greenhouse Gas (GHG) inventory of adult (greater than one year of age) sheep $\left(20.9 \mathrm{~g} \mathrm{CH}_{4} / \mathrm{kg} \mathrm{DMI}\right)$, dairy cattle $\left(21.6 \mathrm{~g} \mathrm{CH}_{4} / \mathrm{kg} \mathrm{DMI}\right)$ and deer $\left(21.5 \mathrm{~g} \mathrm{CH}_{4} / \mathrm{kg}\right.$ DMI) appear to be similar. However, the value used for deer is an

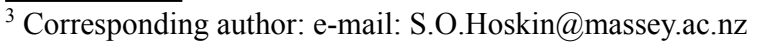


average of adult sheep and dairy cattle, gained from actual methane measurements in those species. Recently, methane measurements from deer have yielded similar values (22.5 $\mathrm{g} \mathrm{CH}_{4} / \mathrm{kg} \mathrm{DMI)} \mathrm{(Swainson,} \mathrm{2004).} \mathrm{However,} \mathrm{young} \mathrm{sheep,} \mathrm{less} \mathrm{than} \mathrm{one} \mathrm{year} \mathrm{of}$ age, consistently produce $20 \%$ less methane, compared with older adult sheep (Lassey et al., 1997; Ulyatt et al., 2005). Similarly, Cavanagh et al. (2004) found that methane yields from beef cattle, aged from 6 months to approximately 14 months $\left(17.8 \mathrm{~g} \mathrm{CH}_{4} /\right.$ kg DMI) appear to be lower than that of mature cattle. However, no studies have been conducted to measure methane emissions from immature deer, especially whilst grazing fresh forage.

As at June 2005, up to $38 \%$ of the NZ deer herd was less than one year of age (Anon, 2006). If immature deer produce less methane than adult deer, then total methane emissions in the NZ GHG inventory for deer may be over-estimated. Therefore, the aim of this study was to test the hypothesis that methane emissions from young deer grazing pasture increase with age.

\section{MATERIAL AND METHODS}

Methane emissions of 20 grazing red deer stags were measured four times postweaning, at 4.5, 6.5, 9 and 11.5 months of age, using the $\mathrm{SF}_{6}$ technique, as described by Pinares-Patiño et al. (2003). Methane equipment was modified to fit young deer and from weaning until the first methane measurement, deer underwent a four week training period to become accustomed to normal handling procedures in the yards and to methane collection equipment, i.e. halters, harness and yoke.

During the experiment, deer rotationally grazed on a permanent pasture containing ryegrass (Lolium perenne cv Nui) (approximately $87 \%$ of the DM) and white clover (Trifolium repens cv Huia) (approximately 2\% of the DM) and were offered pasture ad libitum. Daily pasture allowance was set at $7 \mathrm{~kg}$ DM of "edible" pasture per day per deer. Pasture to estimate the metabolizable energy content of feed on offer was collected by hand plucking. Dry matter intake of deer was estimated using the energy requirements for maintenance $\left(0.57 \mathrm{MJ} \mathrm{ME} /\right.$ liveweight $\left.\mathrm{kg}^{0.75} / \mathrm{d}\right)$, adjusted for season, and growth rate (37 MJ ME/kg liveweight gain) according to Fennessy et al. (1981). Analyses of data were carried out using SAS (Statistical Analysis System, version 9.1; SAS Institute Inc. Cary, NC).

\section{RESULTS}

The chemical composition of pasture feed selected to deer is shown in Table 1. The ash, organic matter digestibility, ME content and crude protein content of the pasture was found to increase $(\mathrm{P}<0.05)$ with time. In contrast, the lignin content of pasture decreased $(\mathrm{P}<0.03)$ over time. 
Table 1. Chemical composition of feed selected pasture samples grazed by deer during methane measurements conducted during March, May, August and October

\begin{tabular}{|c|c|c|c|c|c|}
\hline \multirow{2}{*}{$\% \mathrm{DM}$} & March & May & August & October & \multirow{2}{*}{$\begin{array}{c}\text { Average } \\
\text { SEM }\end{array}$} \\
\hline & \multicolumn{4}{|c|}{$\mathrm{n}=4$} & \\
\hline Ash & $9.8^{\mathrm{a}}$ & $10.0^{\mathrm{ab}}$ & $10.1^{\mathrm{ab}}$ & $10.4^{\mathrm{b}}$ & 0.13 \\
\hline $\mathrm{ADF}^{1}$ & 21.7 & 20.1 & 21.6 & 21.2 & 0.53 \\
\hline $\mathrm{NDF}^{2}$ & 41.6 & 39.0 & 41.3 & 40.5 & 0.95 \\
\hline $\mathrm{CP}^{4}$ & $21.7^{\mathrm{a}}$ & $23.5^{\mathrm{ab}}$ & $23.1^{\mathrm{ab}}$ & $24.6^{\mathrm{b}}$ & 0.69 \\
\hline Lipid & 3.7 & 3.8 & 3.9 & 4.0 & 0.11 \\
\hline $\mathrm{SSS}^{3}$ & 11.8 & 11.7 & 11.7 & 11.6 & 0.64 \\
\hline Lignin & $2.1^{\mathrm{a}}$ & $1.5^{\mathrm{ab}}$ & $1.9^{\mathrm{ab}}$ & $1.3^{\mathrm{b}}$ & 0.26 \\
\hline $\mathrm{OMD}^{5}$ & 82.0 & 84.7 & 82.9 & 85.0 & 0.53 \\
\hline $\mathrm{ME}^{6}$ & 11.9 & 12.5 & 12.15 & 12.6 & 0.10 \\
\hline
\end{tabular}

${ }^{1}$ acid detergent fibre, ${ }^{2}$ neutral detergent fibre, ${ }^{3}$ starch and soluble sugars, ${ }^{4}$ crude protein, ${ }^{5}$ organic matter digestibility, ${ }^{6}$ metabolizable energy $(\mathrm{MJ} / \mathrm{kg} \mathrm{DM})$

Deer liveweight gain within season, coinciding with methane measurements, is shown in Figure 1. It was found that there was a marked effect of season on liveweight gain, driven by the low winter growth rates $(\mathrm{P}<0.001)$. However, there was no significant difference in liveweight gain between the summer, autumn and spring periods.

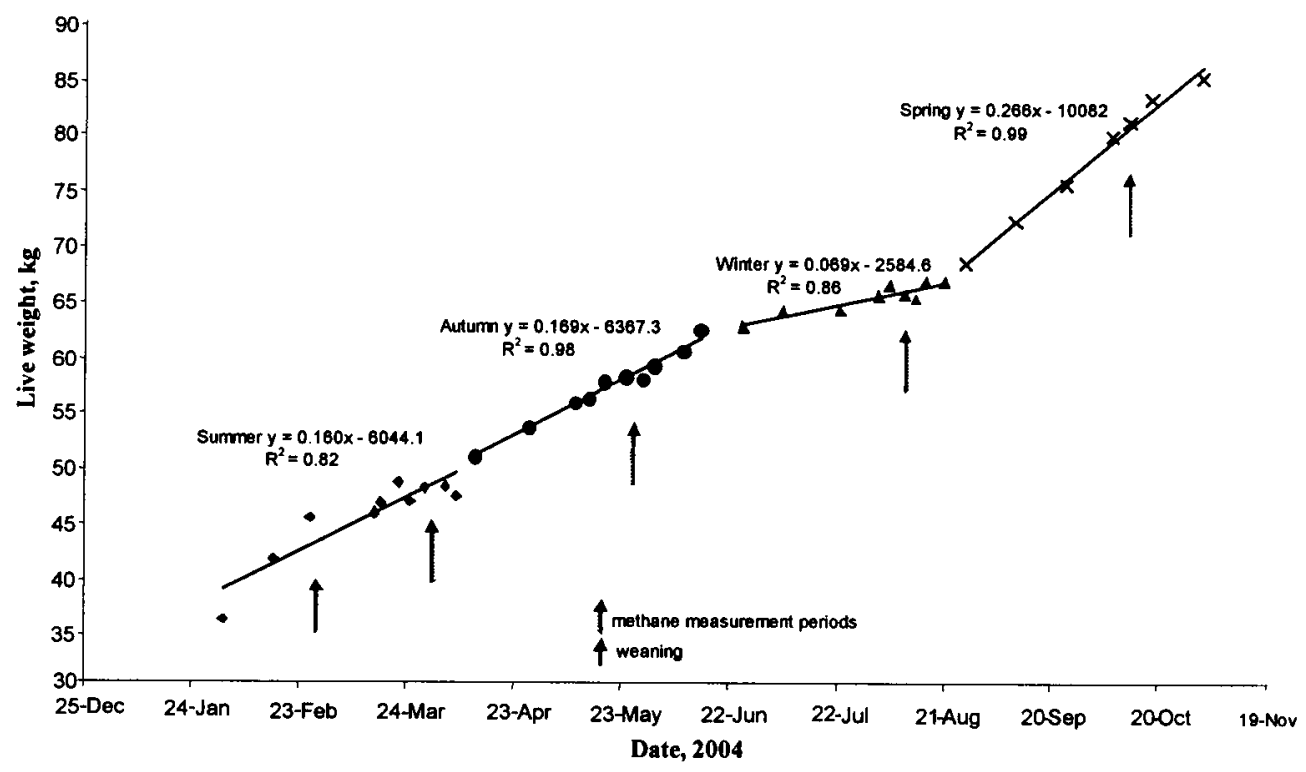

Figure 1. Pattern of liveweight change of red deer stags from before weaning at 3.5 months until one year of age 
Methane production $(\mathrm{g} / \mathrm{d})$, as shown in Table 2, was found to increase with age $(\mathrm{P}<0.0001) ; 4.5$ months $<6.5=9.5<11.5$ months of age. Similarly, methane yield $(\mathrm{g} / \mathrm{kg} \mathrm{DM})$ was also found to increase with deer age $(\mathrm{P}<0.0001)$; 4.5 months $<6.5=9=11.5$ months of age. There was also a trend for methane per kg liveweight to decrease with age $(\mathrm{P}<0.078)$; methane per kilogram of liveweight was lower at 9 and 11.5 months of age than at 4.5 and 6.5 months of age.

Table 2. Dry matter intake (DMI) and methane emissions $\left(\mathrm{CH}_{4}\right)$, production $\left(\mathrm{CH}_{4} \mathrm{~g}\right.$ per day) and yield $\left(\mathrm{CH}_{4}\right.$ per $\left.\mathrm{kg} \mathrm{DMI}\right)$ of weaned red deer stags at 4.5 (March), 6.5 (May), 9 (August) and 11.5 (October) months of age (mean \pm SEM)

\begin{tabular}{lllll}
\hline Age, months & \multicolumn{1}{c}{4.5} & 6.5 & 9 & 11.5 \\
\hline DMI* $^{*}$ & $1.66^{\mathrm{a}} \pm 0.030$ & $1.93^{\mathrm{b}} \pm 0.030$ & $1.85^{\mathrm{b}} \pm 0.031$ & $2.27^{\mathrm{c}} \pm 0.031$ \\
$\mathrm{CH}_{4} \mathrm{~g} / \mathrm{d}$ & $24.6^{\mathrm{a}} \pm 1.11$ & $32.8^{\mathrm{b}} \pm 1.63$ & $32.3^{\mathrm{b}} \pm 1.79$ & $40.1^{\mathrm{c}} \pm 1.68$ \\
$\mathrm{CH}_{4} / \mathrm{kgDMI}$ & $14.9^{\mathrm{a}} \pm 0.57$ & $17.0^{\mathrm{b}} \pm 0.72$ & $17.4^{\mathrm{b}} \pm 0.85$ & $17.7^{\mathrm{b}} \pm 0.75$ \\
$\mathrm{CH}_{4} / \mathrm{kg} \mathrm{LW}$ & $0.51 \pm 0.022$ & $0.57 \pm 0.026$ & $0.48 \pm 0.024$ & $0.48 \pm 0.023$ \\
\hline
\end{tabular}

abc different letters within rows denotes a significant difference of the mean. *DMI based on calculations of energy requirements for maintenance and growth

\section{DISCUSSION}

This study indicates that methane yield and production may increase with age in young deer and may be less that previously reported for adult deer (Swainson, 2004) which agrees with findings in sheep (Lassey et al., 1997; Ulyatt et al., 2005) and cattle (Cavanagh et al., 2004), when the $\mathrm{SF}_{6}$ technique has been employed to measure methane emissions. However, these results conflict with the findings of Graham (1980), which showed that methane production was not affected by age when measured from sheep 2, 4 and 10 months of age and concurrently measured from mature sheep via closed-circuit respiration chambers.

Reasons for reduced methane production and yield in young animals compared with older animals are not clear and may be due to a host of interacting factors. Cellulolytic bacteria and methanogens (Anderson et al., 1987; Skillman et al., 2004) are present in the rumen within the first week of life. Furthermore, Joyce and Rattray (1970) found when using rumen fluid inocula taken from lambs three weeks of age or older, that grass and hay had similar in vitro digestibility to that observed when inocula were taken from adult sheep. This suggests that the microbial population is not limiting fermentation within the digestive tract from approximately 3 weeks of age.

Animal factors rather than microbial factors may have a substantial influence on methane production as animals age. Pinares-Patiño et al. (2003) demonstrated that methane emissions can be influenced by animal factors, i.e. fractional outflow rate of particulate from the rumen and rumen fill. However, little research has been 
conducted to examine these animal factors in young ruminants (post weaning) compared with mature ruminants.

By eight weeks of age, the digestive tract of lambs and calves was thought to function similarly to that of a mature ruminant (Wardorp and Coombe, 1961). However, the relative contribution of the hindgut, versus the foregut, to digestion may change as the animal matures. There is evidence that methane production in the hindgut is lower per unit of feed fermented than that of the rumen (De Graeve and Demeyer, 1988: in Moss, 1993). Oh et al. (1972) found that the proportion of total volatile fatty acids of rumen origin from the digestive tract of lambs increased as the lambs aged. Therefore, changes in the site of digestion may explain the lower methane production from young animals compared with older animals. However, no work of this type has been conducted in deer.

\section{CONCLUSIONS}

Methane production and methane yield from deer in the present study appeared to increase with age and were less than those previously recorded in adult deer. This implies that there may be an overestimation of methane from deer in the New Zealand Greenhouse Gas Inventory if a separate value for deer less than one year of age is not used. However, as this study did not simultaneously measure methane from adult and immature animals consuming the same diet at the same time, absolute differences in methane emissions with age could not be determined from this study. Also, despite little change in this study, a possible confounding factor in this and other studies of Lassey et al. (1997), Cavanagh et al. (2004) and Ulyatt et al. (2005) and showing apparent effects of age on methane emissions of young ruminants, is that in the grazing or pasture-fed situation, possible effects of seasonal changes in dietary chemical composition on methane emissions cannot be ruled out. Further research is needed to investigate the mechanisms by which methane production and yield may be reduced in adolescent animals.

\section{REFERENCES}

Anderson A.E., Nagaraja T.G., Morrill J.L., Avery T.B., Galitzer S.J., Boyer J.E., 1987. Ruminal microbial development in conventionally or early-weaned calves. J. Anim. Sci. 64, 1215-1226 Anon, 2005. Climate Change National Inventory. Report New Zealand Greenhouse Gas Inventory 1990-2003 (including the Common Reporting Format (CF) for 2001), April 2005. New Zealand Climate Change Office, Wellington (New Zealand)

Anon, 2006. Deer Industry Annual Survey. February 2006. Deer Industry New Zealand, Wellington (New Zealand) 
Cavanagh A.J., Molano G., Clark H., 2004. Methane emissions from growing beef cattle grazing hill country pasture. Proceedings of the Workshop on the Science of Atmospheric Trace Gases. NIWA Tech. Report 125, 89-91

Fennessy P.F., Moore G.H., Corson I.D., 1981. Energy requirements of red deer. Proc. N.Z. Soc. Anim. Prod. 41, 167-173

Graham N.McC., 1980. Variation in energy and nitrogen utilization by sheep between weaning and maturity. Aust. J. Agr. Res. 31, 335-345

Joyce J.P., Rattray P.V., 1970. The intake and utilization of milk and grass by lambs. Proc. N.Z. Soc. Anim. Prod. 30, 94-105

Lassey K.R., Ulyatt M.J., Martin R.J., Walker C.F., Shelton I.D., 1997. Methane emissions measured directly from grazing livestock in New Zealand Atmos. Environment 31, 2905-2914

Moss A., 1993. Methane: Global Warming and Production by Animals. Chalcombe Publications, Canterbury (UK), pp. 105

Oh J.H., Hume I.D., Torell D.T., 1972. Development of microbial activity in the alimentary tract of lambs. J. Anim. Sci. 35, 450-549

Pinares-Patiño C.S., Ulyatt M.J., Lassey K.R., Barry T.N., Holmes C.W., 2003. Rumen function and digestion parameters associated with differences between sheep in methane emissions when feed chaffed lucerne hay. J. Agr. Sci. 140, 205-214

Skillman L.C., Evans P.N., Naylor G.E., Morvan B., Jarvis G.N., Joblin K.N., 2004. 16S ribosomal DNA-directed PCR for primers for ruminal methanogens and identification of methanogens colonising young animals. Anaerobe 10, 277-285

Swainson N.M., 2004. Methane emissions from farmed red deer. MSc. Thesis, Massey University, Palmerston North (New Zealand)

Ulyatt M.J., Lassey K.R., Shelton I.D., Walker C.F., 2005. Methane emissions from sheep grazing four pastures in late summer in New Zealand. N.Z. J. Agr. Res. 48, 385-390

Wardrop I.D., Coombe J.B., 1961. The development of rumen function in the lamb. Aust. J. Agr. Res. 12, 661-680 